\title{
CONVEYANCES OF REGISTERED LAND
}

James Edward Hogg

Lincoln's Inn, London

In a former article in this Journal ${ }^{1}$ I pointed out that one great difference between the American system of registration of title to land and the majority of the systems in the British Empire is that under the American system, as illustrated by the provisions of the Draft Uniform Act of 19I4, "the policy is deliberately adopted of allowing all transactions to be carried out by means of ordinary instruments." The purpose of the present article is to set forth some of the possible results of this policy on the juridical theory and the practical working of registration of title.

The subject of transactions with registered land subsequently to its initial registration does not seem to have come up for decision or even discussion in American cases. Niblack says, in an article in this Journal ${ }^{2}$ :

"the courts were content to pass only on the validity of the original registration under a decree in a contested suit, leaving subsequent transfers of the property by the sole act of the registrar entirely out of consideration."

Of the systems belonging to the British Empire-those in Nova Scotia, Ceylon, East Africa, Sudan, British Honduras and British Columbia-which do not insist on the use of instruments of prescribed form in registered transactions, British Columbia is the only one whose law reports contain any cases on the subject, and even of these there are not many. An exception to the general form of statutory instrument has been engrafted on the English and Irish systems, viz., the requirement that these shall be under seal. In all cases where the instrument of assurance- - r rather the instrument on the faith of which assurance of the land is to be effected by appropriate entries on the register-is a deed, and not merely an instrument under hand, undue efficacy is apt to be attributed to the instrument itself and less than its proper efficacy to the registration of the transaction.

The difference between registration statutes that provide for the compulsory use of instruments in prescribed or statutory form, and those that do not, is perhaps not apparent at first sight. The importance of the presence or absence of this one provision is due to the circumstance that its presence in or absence from any particular statute

${ }^{2}$ Registration of Title to Land (1918) 28 Yale LAw JournaL, 5I, 56.

'Pivotal Points in the Torrens System (IgI5) 24 Yale Law Journal, 274, 279. 
is, as a matter of fact, always accompanied by other differences, so that registration statutes under which statutory instruments must be used for registered transactions differ from those under which ordinary instruments may be used in other respects also. These other points of difference will be found to be of even greater importance than the mere use of an instrument in one or another form.

Both classes of statutes-those that do, and those that do not, insist on the use of statutory instruments-agree in making registration essential for effecting any complete assurance of the land. ${ }^{3}$ Notwithstanding considerable difference in detail and in form of enactment, the provision in the American Draft Uniform Act of 1914, requiring all transactions to be registered as a condition of complete validity, may be taken as broadly typical of the corresponding enactment in British statutes. This provision is contained in and forms part of section 47 which is as follows:

"Except as otherwise specially provided by this Act, registered land and ownership therein shall be subject to the same rights, burdens and incidents as unregistered land, and may be dealt with by the owner, and shall be subject to the jurisdiction of the courts, in the same manner as if it had not been registered. But registration shall be the only operative act to transfer or affect the title to registered land, and shall date from the time the writing, instrument, or record to be registered is duly filed and entered in the office of the proper registrar. Subject to the provisions of section 44 , no voluntary nor involuntary transaction shall affect the title to registered land until registered in accordance with the provisions of this Act."

Section 44 of the Draft Uniform Act, referred to in this section, enacts that the registered owner holds his land free from all adverse claims, except those arising through fraud, forgery, unregistered statutory rights, taxes, and occupation leases for a year. A similar enactment forms part of nearly every registration statute.

Among statutes providing for the use of statutory forms, that of Victoria (Australia) may be taken as typical: "The proprietor of land, or of a lease, mortgage or charge, or of any estate, right or interest therein respectively, may transfer the same by a transfer in one of the forms in the seventh schedule"; so as to the right to make leases and mortgages, etc. ${ }^{*}$ Under such enactments as these the statutory method of transferring, leasing, etc., is compulsory in case of all registered transactions, though in some jurisdictions discretion as to insisting on exact compliance with prescribed forms is expressly

\footnotetext{
s The exception may be neglected for the present purpose.

- See Victoria: Transfer of Land Act, 1915, secs. 121, I3I, 145, printed in Hogg, Registration of Title to Land throughout the Empire (1908) 424, 426, 430. Or see New South Wales: Real Property Act, 1900, secs. 46, 53, 56, printed in Hogg, Australian Torrens System (1905) 108, 110, III.
} 
allowed to the registry office. ${ }^{5}$ This compulsory use of statutory instruments is, however, confined to certain stated transactions, and though the statutory instruments may be modified so as to embrace most ordinary transactions, statutes of this class are very far from requiring every instrument affecting land to be registered. No provision, for instance, is made for the registration of contracts for sale. The provision, therefore, that "no instrument until registered . . . shall be effectual to pass any estate or interest in any land," does not apply to every instrument affecting land, but only to such instruments as are registrable.

It therefore appears that systems of registration of title that make provision for compulsory use of statutory instruments differ from those that do not on two points: Only statutory instruments are registrable, and ordinary instruments are not to be used for registrable transactions. In the systems that make no provision for compulsory use of statutory instruments, every instrument affecting land is registrable, and ordinary instruments may, and in effect must, be used for registrable transactions.

It will be found that systems in which no provision is made for compulsory use of statutory forms differ from other systems in practical working and juridical theory in the following ways: (I) All transactions subsequent to initial registration will be in the nature of original or initial applications for registration, and will require the exercise of considerable judicial discretion on the part of the registry office; (2) professional assistance in the preparation of the simplest conveyance or mortgage will be almost indispensable; (3) the nature of the rights conferred by the execution of a conveyance, mortgage, etc., and pending registration will be difficult to determine, and will not necessarily be governed by the analogy of other systems; (4) in the case of mortgages the nature of the right conferred on the mortgagee both before and after registration will be still more difficult to determine, since the ordinary form of mortgage in fee will continue to be a "sham conveyance" and will not be a statutory charge as under other systems.

The first two of these points may be dealt with together. The utility of statutory forms of instruments lies in their saving the necessity of legal assistance in the majority of simple transactions, and enabling the registration to be carried out almost automatically, thus making the function of the registry officers ministerial rather than judicial. These advantages are lost where ordinary assurances continue to be employed. The use of technical words, and of clauses conferring

\footnotetext{
'Crowley v. Templeton (1914, H. C. Austr.) I7 C. L. R. 457; and see Hogg, Registration of Title to Land throughout the Empire (1908) $2 \mathrm{Ir}$.

'Victoria: Transfer of Land Act, 19I5, sec. 6r, printed in Hogg, ibid., 4II ; New South Wales: Real Property Act, 1900, sec. 4I, printed in Hogg, Australian Torrens System (1905) 106.
} 
express powers and embodying express covenants, is inseparable from the ordinary form of conveyance, lease or mortgage. Such documents cannot be prepared by a layman, and their meaning and effect cannot be properly appreciated by laymen. A higher degree of legal equipment will be required in the registry officers, and each transaction will have to be much more closely scrutinized than if simple and wellunderstood forms were employed. Every transaction will thus tend to resemble an application for initial registration, in which the applicant's title has to be investigated as on the sale and purchase of land. This must inevitably impede the smooth and rapid working of the registry.

With respect to the nature of the rights conferred by ordinary conveyances or mortgages pending registration, the difficulty of determining what effect is to be given to an unregistered instrument, when registration is made "the only operative act to transfer or affect the title" to the land, is dual: Is the right conferred an actual interest in the land? If so, is it an equitable interest, or if not an equitable interest how is it to be described? There is no question about its being a legal interest, for the legal interest or complete ownership is only conferred by registration. The question resolves itself into the following alternatives: The unregistered instrument confers either an equitable interest, or an interest that is neither legal nor equitable, or else a mere personal right, like a chose in action, that is not an interest in the land at all. But the last of these three alternatives may be dismissed with little more than its mere statement. The view that an unregistered instrument confers a mere personal right and nothing that can be called an interest in land does not seem tenable on any ground of principle or authority. The real choice lies between an interest that can properly be described as equitable and one that cannot be so described. To a great extent it is a matter of words, and if the interest conferred by the unregistered instrument is not "equitable," how is it to be described?

In the majority of systems of the Australian type the view has generally been taken that interests conferred by recognized but unregistrable instruments, such as contracts for the sale of land, are true equitable interests. The difficulty has been to find a suitable name for interests conferred by unregistered registrable instruments. The Australian case of Barry v. Heider ${ }^{8}$ illustrates this. This case arose under the New South Wales registration statute. A statutory form of transfer of land had been executed under circumstances that rendered it voidable. While still unregistered the transferee executed a mortgage over the land. Before either transfer or mortgage were

\footnotetext{
7 "Registration is the operative act to convey title." Tyler v. Court of Registration (1900) 775 Mass. 7I, 80, 55 N. E. 812.

${ }^{8}$ (I9I4, H. C. Austr.) I9 C. L. R. 197, under the New South Wales: Real Property Act, I900, referred to in note 4, supra.
} 
registered proceedings were taken by the transferor to set the transfer aside. The mortgagee claimed to have such an interest in the land as entitled him to keep his security as a charge on the land, notwithstanding that the transferor was entitled to avoid the transfer as against the transferee. This claim was upheld, on the ground that the unregistered transfer conferred on the transferee an interest which he was entitled to deal with, and the transfer being voidable only and not void, the right of the mortgagee was better than and must be held prior to the right of the original transferor. Two judgments were delivered. That of Griffith, C. J. proceeded on the broad view that, notwithstanding the enactment, "no instrument until registered . . . shall be effectual to pass any estate or interest in" land, "equitable claims and interests are recognized by the" registration statute; the equitable claim or right conferred by the unregistered transfer "was in its nature assignable by any means appropriate to the assignment of such an interest." The judgment of Isaacs, J. was more elaborate. He admitted that under the enactment above quoted the registrable instrument would not pass any estate, legal or equitable, but he proceeded to draw the distinction, referred to above, between "rights" created by ordinary unregistrable instruments and those created by a statutory registrable instrument. The learned judge said :

"The Land Transfer Act does not touch the form of contracts . . . Consequently sec. $4 \mathrm{I}$, in denying effect to an instrument until registered, does not touch whatever rights are behind it. Parties may have a right to have such an instrument executed and registered; and that right, according to accepted rules of equity, is an estate or interest in the land. Until that instrument is executed, sec. 4I cannot affect the matter, and if the instrument is executed it is plain its inefficacy until registered-that is, until statutory completion as an instrument of title-cannot cut down or merge the pre-existing right which led to its execution."

The position then was the same, "as to equitable remedies, as if the land were not under the" registration statute. It would be in accordance with the views expressed in Barry $v$. Heider by both judgments to call the interest under the unregistered and registrable instrument a "right to registration."

The Irish courts have gone much further in laying down the doctrine that "no estate, legal or equitable, passed from the transferor to the transferee until registration." The words of the Irish enactment are: "Until the transferee is registered as owner of the land (the instrument of transfer) shall not confer on the transferee any estate

\footnotetext{
'Barry v. Heider, supra, 216.

${ }^{20}$ Pim v. Coyle (1907) I L. R. Ir. 330. Other trial cases are cited in Hogg, Registration of Title to Land throughout the Empire (1908) II4.
} 
in the lands." 11 In Pim v. Coyle the transferee neglected to register until after a judgment-mortgage had been registered against the transferor. It was held that the whole interest of the transferor was bound by the registered judgment-mortgage in priority to any interest of the transferee. The Irish statute, like the Australian statutes, makes no provision for the general registration of instruments, such as contracts for sale, etc. The interest of a person entitled to be, but not yet, registered has been described in another Irish case as "an inchoate right incapable of being defeated, and only waiting for an official duty to be performed to become an absolute estate."12 This right to registration would aptly be so described.

A system much nearer to the American system is that of British Columbia, where the statutes contemplate the use of ordinary forms of conveyance and provision is made for the registration of all instruments affecting land. ${ }^{13}$ By section IO4 of the I9I I statutes no instrument purporting to affect land "shall pass any estate or interest either at law or "in equity in such land until" registered; but the rights conferred by the unregistered instrument are expressly made assignable, and so must confer an interest of some kind in the land: "such instrument shall confer on the person benefited thereby and on those claiming through or under him, whether by descent, purchase or otherwise, the right to apply to have the same registered." The unregistered instrument thus confers, if not an equitable interest, a right to registration.

The above enactment has given rise to some difficulty and to difterences in judicial opinion, ${ }^{14}$ but in a case before the Privy Council the enactment was construed quite literally. ${ }^{15}$ Howard $v$. Miller related to a claim for specific performance of an agreement for the sale of land. . In the course of the judgment delivered by Lord Parker it was said :

"The agreement of June I, Ig08, was, in their Lordships' opinion, an instrument purporting to affect land, and therefore, required registration under s. 74 of the Act. When so registered (but not before) it would confer on the plaintiff Miller an equitable interest his title to which would be registrable in the Register of Charges."

On the other hand the courts in British Columbia have in some cases treated section 104 of the I9I I statute like any other mere registration enactment and as being chiefly important in its effect on third parties'

12 Ireland: Local Registration of Title Act, 1891 (54 and 55 Vict. ch. 66), sec. 35 .

${ }^{12}$ In re Furlong and Brogan's Contract (1893) 31 L. R. Ir. I9r.

${ }^{13}$ British Columbia: Land Registry Act (Rev. St. 19II, ch. 127) and many amending statutes. See Hogg, Registration of Title to Land throughout the Empire (1908) I2.

"Cases are cited in Hogg, ibid., II5.

${ }^{15}$ How'ard v. Miller [19I5] A. C. 318. 
rights. For instance, it has been held that a purchaser under a conveyance not yet registered can claim compensation for injury to the land, notwithstanding section I04:

"He was, as between himself and his vendor, the equitable owner of the land when the damage was. done, and who, as between himself and his vendor, was the one injured, and who, before taking these proceedings, perfected his title by getting in the legal estate and complying with sec. I04."18

So a conveyance made by way of security, when registered, was held prior in interest to a creditor's deed of assignment executed after but registered before the conveyance; on registration the conveyance was held to relate back to the date of execution..$^{17}$

The cases cited-and particularly those under the British Columbia statutes, support the view that, where statutory instruments are not provided for, an instrument in the ordinary form of a deed would not, until registered, pass any estate, legal or equitable. If that be so, then a formal deed of conveyance or mortgage would have no greater effect than a mere contract or agreement under hand. In the words of another judgment of the Privy Council13_-"no instrument is effective to convey any estate in land unless it is registered, and therefore the effect of the instrument rested in contract until registration." If it be said that even under a contract for sale the purchaser would have an equitable estate, the answer is that a contract for sale would equally fail to "affect the title" until registered, so that in the end mere agreements and formal conveyances would be on the same footing-they would all "rest in contract" until registered, and the interest they would confer would be best described as a right to registration, assignable and carrying with it many of the attributes of an equitable interest. Although an interest in the land, it would not properly speaking be the ordinary equitable estate or interest of English law. Possibly statutes made as the American and British Columbia statutes-requiring all instruments affecting land to be registered-have gone much farther than the Australian statutes in abrogating the equitable estate of English law, and have approximated to the doctrine of the civil law as illustrated in South Africa. The following extract from a judgment of the Privy Council shows the difference between English and Roman-Dutch law :

"It is true that by the law of Natal a purchaser of land, though he may have paid the price, is not until regular legal transfer (which includes

${ }^{16}$ Re North Vancouver City \& Jackson (1914, B. C. Ct. App.) 27 West. L. R. 456 .

${ }^{1 T}$ Westfall v. Stewart (Ig07) 13 B. C. R. III.

${ }^{13}$ Loke Yew v. Port Swettenham Rubber Co. [1913] A. C. 491, 500-under the Federated Malay States statute, which goes to extreme lengths in prohibiting non-statutory assurances. 
registration) the owner of the land, but is only one who has a claim against the vendor. To speak of him as the true owner in the language of an English Court of Equity, though the expression may be used in speech for brevity's sake, is not correct .. . he is a creditor of a very special kind-one who, in the absence of other claimants, has a right to demand the very property in dispute."19

The change in the form and theory of mortgages is one of the most considerable of all the changes made by systems of registration of title under which provision is made for the compulsory use of statutory instruments. The statutory mortgage, thus introduced, takes the place of the old sham conveyance of English law, and operates as a charge on the land with statutory powers in the mortgagee for enforcing his security. It is, however, "now generally recognized under the English system, although old forms are still used, that the real owner of the land is the mortgagor, and the mortgage is a mere security for the debt or obligation." 20 In those systems of registration which have not introduced the statutory mortgage the "real ownership" of the mortgagor and the "mere security" of the mortgage by conveyance seem necessarily to be recognized in an even stronger degree than in ordinary English law. It has been said of the British Columbia system: "A clear line of demarcation has been drawn between ownership of the fee and of a charge," 21 and the statutes do in point of fact treat all mortgages as charges only and not as conveyances of the ownership of the land.

Nevertheless the continued use of the English form of mortgagea mere sham conveyance-must necessarily cause difficulty in a system of registration of title. The systems that contemplate the use of the ordinary mortgage in fee are also the systems that require all instruments to be registered, so that the considerations applicable to contracts for sale and conveyances, already referred to, will also apply to mortgages so long as these remain unregistered. Until registration they "rest in contract," and take effect as agreements only and not as true mortgages giving rights in re; an unregistered mortgage-to adopt the language of another Privy Council judgment which seems applicable- "is valueless as a transfer or burdening instrument, but it is good as a contract." 22

The effect of the registration and the operation of the registered mortgage is another matter altogether. The mortgage then takes effect as a "burdening instrument," and the question to determine is how far the registered ownership of the mortgagor is interfered with,

${ }^{19}$ Crozely v. Bergtheil [1899] A. C. 374, 390, 391.

${ }^{20}$ Mutual Life Ins. Co. v. Douglas (1918, Can.) 57 S. C. R. 273.

${ }^{2}$ Bank of Hamilton v. Hartery (19I8, Can.) 3 Weekly West. R. 551.

$=$ Haji Abdul Rahman v. Mahomed Hassan [19I7] A. C. 209, 215, a case on the Federated Malay States statutes. 
apart from the effect of the mortgage as a charge-assuming of course that the ordinary form of a mortgage in fee is used. Of the many subsidiary questions that could be raised about this, one typical question would be: How is the land to be assured to a purchaser in the event of realization being necessary? Under the British Columbia system the mortgage would be registered as a charge only, and the mortgagee would not be registered as the owner of the land. This would seem to be so equally under the American system. Notwithstanding the words of conveyance in the mortgage then, the mortgagee would not take the registered ownership, but this would remain in the mortgagor. No statutory powers being conferred on the mortgagee, he would be unable to vest the registered ownership in a purchaser either by virtue of the conveyance to himself or of any power conferred on him by the registration statute. Apparently a conveyance to a purchaser could only be made in two ways: By virtue of an express conventional power contained in the mortgage deed and so drawn as to enable the mortgagee to authorize the registry office to pass the registered ownership from the mortgagor to the purchaser; or under an order of court made in proceedings taken $a d$ hoc by the mortgagee.

Thus not only is the simple theory of the statutory charge, as existing in the Australian type of registration of title, absent from the American and British Columbia types, but also the simpler method of carrying out and enforcing mortgage transactions. While the theory of mortgages is, if anything, made more difficult than even under ordinary English law, the practical business of mortgaging land and realizing the security is also made quite as troublesome and expensive as in the case of unregistered land, and much more troublesome and expensive than under systems of registration of title which provide for a statutory mortgage by way of charge.

On all four points above referred to the system of employing ordinary assurances for carrying out transactions with registered land appears to be less satisfactory, both in juridical theory and in practical convenience, than the system of employing special instruments in statutory form. 